\title{
Combined Effect of Aflatoxin and Vitamin A on Clastogeny in Mice Chromosomes
}

\author{
Dharmshila Kumari and S. P. Sinha \\ Post-Graduate Department of Zoology, Bhagalpur University, \\ Bhagalpur-812007, India
}

Accepted February 16, 1990

Mycotoxins are secondary metabolites of toxigenic strains of certain fungi. Aspergillus flavus is one such very common fungus that infests food and feed commodities (Ranjan 1986), and elaborates a toxic substance called aflatoxin. The most common aflatoxin is $B_{1}\left(A F-B_{1}\right)$, though $B_{2}, M_{1}, M_{2}, G_{1}$ and $G_{2}$ forms are also found. Dietary concentrations of AF- $B_{1}$ have been reported to be mutagenic (Sinha et al. 1987, Bilgrami and Sinha 1988), teratogenic and carcinogenic (Butler 1974, IARC 1976, Bilgrami et al. 1986a, b). Sincere efforts therefore, must be made to protect the domesticated animals, poultry birds and even human beings from its hazards. Vitamin C is one such bioantimutagen (Sinha and Bose 1989) that could minimise the genotoxicity and general toxicity (Bilgrami et al. 1989) of aflatoxin. Present experiments were, therefore, designed with an aim to find out similar effects, if any, of another vitamin, the vitamin $\mathrm{A}$, which has also been shown to prevent, delay or retard carcinogenesis induced in laboratory animals by a variety of chemicals (Moon et al. 1983, Newberne and Rogers 1981, Sporn and Newton 1981).

\section{Material and method}

Four to five-week old albino Swiss mice (Mus musculus) of both sexes, obtained from an inbred laboratory stock, were used. The animals were separated into six groups, and were subjected to various treatments. The vitamin was administered either along with the toxin or as a post- or pre-treatment to toxin feeding. Three types of control were used: toxin only, vitamin only, neither toxin nor vitamin. The general plan of administration is given in Table 1. Two repeats of experiment were performed, each with six animals matched for their sex and age.

It is worth-remembering that the dose of toxin is almost the same which the population usually and inadvertantly takes in with food and feed. The dose of vitamin $A$ is proportionate to the dose recommended for human body (therapeutic dose). Vitamin A (as palmitate "Aquasol-A") used in this study was provided by U.S. Vitamin (India) Ltd. Animals were sacrificed after a week of the termination of the treatment, and chromosome preparations of bonemarrow cells were made following sodium citrate-aceto-alcohol-flame drying-Giemsa staining technique (Kilian et al. 1977). 200 well-spread metaphase plates from each group of animals were screened after random selection at the rate of 15-20 plates per animal.

\section{Results and discussion}

Both gross and individual types of abnormalities were found in all the variants. Their rate in toxin-treated animals was significantly higher than in the control variant, the rate being equal irrespective of 6 or 12 weeks of the treatment (Sinha and Bose 1989). The overall frequency of cells with chromosomal abnormalities was found to be higher in vitamin-treated 
mice which may be due to hypervitaminosis (Elsas and McCormick 1986). Not only the pre- and post- administration of vitamin A, but also its concurrent administration were poorly efficacious in minimising the total frequency of aflatoxin-induced abnormalities.

Table 1. Summary of the experimental protocol

\begin{tabular}{|c|c|c|}
\hline Experimental variants & Symbol & Description \\
\hline 1. Toxin only & $\mathbf{T}$ & $\begin{array}{l}0.05 \mu \mathrm{g} \text { of toxin/animal } / \mathrm{kg} . \mathrm{b} . \text { wt. daily with food } \\
\text { for } 6 \text { and } 12 \text { weeks in } 50 \pm 10 \mathrm{ppb} \text { concentration. }\end{array}$ \\
\hline 2. Vitamin only & $\mathrm{V}$ & $\begin{array}{l}66.06 \mathrm{I} \text {. U. of vitamin } \mathrm{A} / \mathrm{animal} / \mathrm{kg} \text {. b. wt. daily for } \\
12 \text { weeks through intubation. }\end{array}$ \\
\hline 3. No treatment & $\mathrm{C}$ & No administration of toxin or vitamin. \\
\hline 4. Toxin and vitamin together & $\mathrm{T}+\mathrm{V}$ & $\begin{array}{l}\text { The toxin (dose as in } 1 \text { ) and vitamin (as in } 2 \text { ). } \\
\text { administered together for } 12 \text { weeks. }\end{array}$ \\
\hline 5. Toxin feeding after vitamin feeding & VT & $\begin{array}{l}\text { Vitamin treatment for } 6 \text { weeks followed by toxin } \\
\text { treatment for another } 6 \text { weeks (doses as in } 1 \text { and } 2 \text { ). }\end{array}$ \\
\hline $\begin{array}{l}\text { 6. Toxin feeding followed by vitamin } \\
\text { feeding }\end{array}$ & TV & $\begin{array}{l}\text { The toxin treatment (dose as in 1) for } 6 \text { weeks } \\
\text { followed by vitamin treatment (dose as in 2) for } \\
\text { remaining } 6 \text { weeks. }\end{array}$ \\
\hline
\end{tabular}

Table 2. Incidence of chromosomal abnormalities in bone marrow cells of mice treated with aflatoxin and vitamin $\mathrm{A}$

\begin{tabular}{|c|c|c|c|c|c|}
\hline & \multirow{3}{*}{ 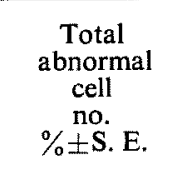 } & \multicolumn{4}{|c|}{ Abnormality types } \\
\hline & & \multicolumn{2}{|c|}{ Individual type } & \multicolumn{2}{|c|}{ Gross type } \\
\hline & & $\begin{array}{l}\text { No. } \\
\% \pm \text { S. E. }\end{array}$ & $\begin{array}{l}\text { Description of } \\
\text { abnormality }\end{array}$ & $\begin{array}{l}\text { No. } \\
\% \pm \text { S. E. }\end{array}$ & $\begin{array}{l}\text { Description of } \\
\text { abnormality }\end{array}$ \\
\hline $\mathrm{C}$ & $\begin{array}{c}10 \\
5.0 \pm 1.54\end{array}$ & $\begin{array}{c}04 \\
2.0 \pm 0.98\end{array}$ & $\mathrm{af}=3, \mathrm{Ctb}=1$ & $\begin{array}{c}06 \\
3.0 \pm 1.20\end{array}$ & $\begin{array}{l}\text { Poly-2, C-mito-1, } \\
\text { Clum-1, Hypo-2 }\end{array}$ \\
\hline $\mathrm{V}$ & $\begin{array}{c}34 \\
17.0 \pm 2.65^{\mathrm{a}} \mathrm{b}\end{array}$ & $\begin{array}{c}12 \\
6.0 \pm 1.67^{a, b}\end{array}$ & $\begin{array}{l}a f=8, C t b=3, \\
C t g-1\end{array}$ & $\begin{array}{c}22 \\
11.0 \pm 2.21^{\mathrm{B}}\end{array}$ & $\begin{array}{l}\text { Poly-1, C-mito-1, } \\
\text { Clum-2, Hypo-18 }\end{array}$ \\
\hline $\mathbf{T}$ & $\begin{array}{c}64 \\
32.0 \pm 3.29^{\mathrm{a}, \mathrm{c}}\end{array}$ & $\begin{array}{c}35 \\
17.5 \pm 2.68^{\mathrm{a}, \mathrm{e}}\end{array}$ & $\begin{array}{l}\text { af }=21, \text { Ctb-5, } \\
\text { Ring-1, Ctg-3, } \\
\text { Ictb-3, Mc-2 }\end{array}$ & $\begin{array}{c}32 \\
16.0 \pm 2.59^{a}\end{array}$ & $\begin{array}{l}\text { Poly-2, C-mito-5, } \\
\text { Clum-6, Stick-2, } \\
\text { Hypo-17 }\end{array}$ \\
\hline $\mathrm{V}+\mathrm{T}$ & $\begin{array}{c}51 \\
25.5 \pm 3.08^{\mathrm{a}}\end{array}$ & $\begin{array}{c}09 \\
4.5 \pm 1.46^{b}\end{array}$ & $\begin{array}{l}\text { af }=5, \mathrm{Mc}-1 \\
\mathrm{Ctb}-2, \mathrm{Ctg}-1\end{array}$ & $\begin{array}{c}44 \\
22.0 \pm 2.93^{\mathrm{a}, \mathrm{c}}\end{array}$ & $\begin{array}{l}\text { Poly-3, Hyp-35, } \\
\text { Clum-2, Stick-1, } \\
\text { C-mito-3 }\end{array}$ \\
\hline VT & $\begin{array}{c}58 \\
29.0 \pm 3.20^{\mathrm{g}}\end{array}$ & $\begin{array}{c}14 \\
7.0 \pm 1.80^{\mathrm{a}, \mathrm{b}}\end{array}$ & $\begin{array}{l}\text { af }=7, \text { Ctb-2, } \\
\text { Ictb-1, Ctg-4 }\end{array}$ & $\begin{array}{c}46 \\
23.0 \pm 2.97^{\mathrm{a}, \mathrm{c}}\end{array}$ & $\begin{array}{l}\text { Poly-3, Hyp-33, } \\
\text { Stick-2, Clum-2, } \\
\text { C-mito-6 }\end{array}$ \\
\hline TV & $\begin{array}{c}47 \\
23.3 \pm 2.99^{a}\end{array}$ & $\begin{array}{c}19 \\
9.5 \pm 2.07^{\mathrm{a}}\end{array}$ & $\begin{array}{l}\text { af }=8, \text { Ctb-6, } \\
\text { Ring-1, Mc-1, } \\
\text { Ctb-3 }\end{array}$ & $\begin{array}{c}30 \\
15.0 \pm 2.52^{\mathrm{a}}\end{array}$ & $\begin{array}{l}\text { Poly-2, C-mito-4, } \\
\text { Stick-2, Hyp-22 }\end{array}$ \\
\hline
\end{tabular}

a,b,c indicate significant difference with corresponding value in the control, toxin and vitamin variants, respectively.

af=acentric fragment; Ictb=isochromatid break; Stick=stickiness; Ictg=isochromatid gap; Poly = polyploid $\mathrm{Ctb}=$ chromatid break; Hypo = hypoploid $\mathrm{Ctg}=$ chromatid gap; Clum $=$ clumping; $\mathrm{Mc}=$ metacentric chromosome; $\mathrm{C}-\mathrm{mito}=\mathrm{C}$-mitosis.

By considering the individual type abnormalities separately, the concurrent administration of aflatoxin with vitamin A, as well as the pre-treatment with vitamin A could significantly minimise the toxin-induced abnormality rate. The gross type abnormalities remained least affected. Thus, vitamin A (as palmitate) shows some protective effect against aflatoxininduced chromosome/chromatid breaks. It can be therefore said that the vitamin A somehow repaired the toxin-induced breaks, but it failed to combat the damages induced in mitotic ap- 
paratus, the latter being generally responsible for gross type abnormalities. The exact mechanism of the antimutagenic property of vitamin $A$ is not known, but the spectrum of effects observed in the present study is in conformity with the observations made by earlier workers, who in in vitro kinetic studies found that retinol inhibits AF- $B_{1}$-DNA adduct formation by virtue of its ability to interact with microsomal enzyme component(s), thereby interferring competitively with the bioactivation of AF-B (Firozi et al. 1987, Bhattacharya et al. 1989). Specific interaction of vitamin A with microsomal enzyme component (s) in relation to AF- $B_{1}$ metabolism, however, is still to be ascertained.

\section{Acknowledgement}

Financial assistance from CSIR (Grant No. 38(642)/86, EMR-II) is thankfully acknowledged.

\section{Summary}

Therapeutic dose (66.06 I. U.) of vitamin A, when administered concurrently with or as a pre-treatment to crude aflatoxin $(0.05 \mu \mathrm{g})$ administration (per oral) for 12 weeks to albino Swiss mice, Mus musculus, could cause significant decrease in the incidence of toxin-induced

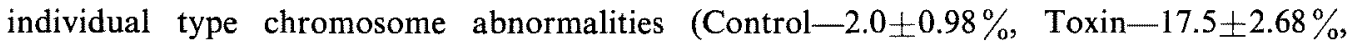
$\mathrm{V} \rightarrow \mathrm{T} 7.0 \pm 1.80 \%, \mathrm{~V}+\mathrm{T} 4.5 \pm 1.46 \%$; the incidence of gross type abnormalities remained unaffected. Post-treatment with vitamin was ineffective in minimising the clastogeny. The toxin alone could induce changes like chromatid break, chromatid gap, metacentric chromosome, acentric fragment, polyploidy, clumping, stickiness, etc. It is suggested that supplementation of food with vitamin A can be useful to combat the genotoxicity of aflatoxin.

\section{Literature Cited}

Bhattacharya, R. K., Prabhu, A. L. and Aboobaker, V. S. 1989, In vivo effect of dietary factors on the molecular action of aflatoxin $B_{1}$ : Role of vitamin $A$ on the catalytic activity of liver fractions. Cancer Letters 44: 83-88.

Bilgrami, K. S. and Sinha, S. P. 1988. Mutagenic Effects of Mycotoxin The Allied Press, Bhagalpur.: pp. 16-19.

-, - and Ranjan, K. S. 1986a. Effect of aflatoxin $B_{1}$ on mitotic index. Curr. Sci. 55: 1092-1094.

-, Ranjan, K. S. and Sinha, S. P. 1986b. Aflatoxin-induced histopathology of skin in guineapigs. Proc. Indian Natn. Sci. Acad. B52: 280-283.

-, Sinha, S. P. and Ranjan, K. S. 1989. Modulation of protective effects of vitamin C in aflatoxicoses. Curr. Sci. $58: 820-821$.

Butler, W. H. 1974. Aflatoxin in Mycotoxins (edt. F. H. Purchase). Elsevier Sci. Pub. Co., Amsterdam: 1-28.

Elsas, L. J. and McCormick, D. B. 1986. Genetic defects in vitamin utilization Part 1: General aspects and fat-soluble vitamins. Vitamin and Hormones 43: 117.

Firozi, P. F., Aboobaker, V. S. and Bhattacharya, R. K. 1987. Action of vitamin A on DNA adduct formation by aflatoxin $B_{1}$ in a microsome catalyzed reaction. Cancer Letters 34: 213-220.

IARC 1976. Lyon, Int. Agency Res. in Cancer 10: 51-52.

Kilian, D. T., Moreland, F. M., Legator, M. S. and Whorton, E. B. 1977. Handbook of Mutagenicity Test Procedures (edt. B. J. Kilbey). Elsevier Sci. Publ. Co. (NY): 243-250.

Moon, R. C., McCormick, D. L.. and Mehta, R. G. 1983. Chemoprevention of animal tumors by retinoids. in: F. L. Meyskens and K. N. Prasad (eds.) Modulation and Mediation of Cancer by Vitamin A. Karger, Basel: 47-57.

Newberne, P. M. and Rogers, A. E. 1981. Vitamin A retinoids and cancer. in: G. R. Newell and N. M. Ellison (eds.) Nutrition and Cancer; Etiology and Treatment. Raven, New York.: 217-232.

Ranjan, K. S. 1986. Survey of different types of animal feed in relation to aflatoxin elaboration. Biol. Bull. of India 8: 187-193. 
Sinha, S. P., Bilgrami, K. S. and Veena Prasad 1987. Aflatoxin-induced clastogeny in bone-marrow cells of mice (Mus musculus). Proc. Indian Natn. Sci. Acad. B53: 215-220.

- and Bose, S. 1989. Vitamin C mediated minimisation of clastogeny induced by dietary concentration of aflatoxin. Proc. of National Symposium on Harmful Effects of Common Environment Toxicans. Om Prasad (ed), Allahabad University, India: 95-99.

Sporn, M. B. and Newton, D. L. 1981. Retinoids and chemoprevention of cancer. in: M. S. Zedeck and M. Lipkin (eds.), Inhibition of Tumor Induction and Development. Plenum (NY).: 77-100. 